\title{
The Partisan and His Doppelganger: The Case of Primo Levi
}

Ilona Klein

ilona_klein@byu.edu

Follow this and additional works at: https://scholarsarchive.byu.edu/facpub

Part of the European Languages and Societies Commons, and the Italian Literature Commons

\section{Original Publication Citation}

"The Partisan and His Doppelganger: The Case of Primo Levi," in Answering Auschwitz: Primo Levi's Science and Humanism after the Fall, ed. Stanislao Pugliese (New York: Fordham Univ. Press, 2011): $114-126$.

\section{BYU ScholarsArchive Citation}

Klein, Ilona, "The Partisan and His Doppelganger: The Case of Primo Levi" (2011). Faculty Publications. 3823.

https://scholarsarchive.byu.edu/facpub/3823

This Book Chapter is brought to you for free and open access by BYU ScholarsArchive. It has been accepted for inclusion in Faculty Publications by an authorized administrator of BYU ScholarsArchive. For more information, please contact ellen_amatangelo@byu.edu. 
CHA P TER 8

\section{The Partisan and His Doppelganger: The Case of Primo Levi \\ Ilona Klein}

Published in 1982 , Se non ora, quando? (If Not Now, When?) is Primo Levi's first novel proper. Perhaps Primo Levi so regretted not fully living life as an Italian Jewish partisan that he re-created his lost dream through its pages, and had his partisan brigade not been captured, perhaps Levi's underground fighting might have continued until the end of the war. If Not Now, When? thus might reflect Levi's need to explore that soughtafter life as a partisan, which he had been denied after only three months of activity. ${ }^{1}$ Did Levi write If Not Now, When? as a mental antidote to his arrest? Was he trying to re-create for himself the underground world of freedom fighters, which he was not able to fulfill? Edoardo Bianchini points out that the main theme of the novel is to reclaim human dignity. During the time in which the fictional core of If Not Now, When? takes place, Primo Levi was a prisoner in Auschwitz. Since it is obvious that, while Levi was interned, he could not simultaneously also be a free man, I propose here that If Not Now, When? might be read and understood as the "other" story, the narrative of that partisan experience that Levi did not live in full, the story of his destroyed dream as an aspiring freedom fighter against the Nazi and Fascist tragedy. I submit, then, that the narrative of If Not Now, When? develops the theme of Levi's doppelganger through the discourse of a fictional, projected alter-ego protagonist. In the 
novel, Levi focuses on the vicissitudes of a group of Jewish partisan fighters of Eastern Europe, celebrating their courage and writing about their adventures perhaps as a way to counteract the misperception that Jews went to the gas chambers without trying to resist arrest and deportation.

The framework for this novel is not entirely fictional. Levi explained, in the author's note following the end of the book, that Emilio Vita Finzi "marrated to me the kernel of the story," for Vita Finzi had "worked as a volunteer at the assistance center [in Milan] described in the final chapter" (347-348). Moreover, Levi acknowledges that the resistance actions described in his novel are "invented but plausible. . . Actions of harassment such as sabotaging railroads ... are amply documented in the literature on partisan warfare in Eastern Europe" (348).

As Primo Levi wrote in the first chapter of Se questo è un uomo (Survival in Auschwitz), he was arrested by the Fascist militia on December r3, I943. By then, he had spent about three months in the Italian regions of Val d'Aosta and Piedmont as part of a small Italian partisan brigade of young and inexperienced men. ${ }^{2}$ During the interrogation following his arrest, Levi declared himself to be an "Italian citizen of the Jewish race." As his readers know, the long agony of Auschwitz and its aftermath were the consequences of such a statement.

A cursory glance at the table of contents of If Not Now, When? clearly shows that the fictional narrative time frame of this novel spans from July I943 through August 1945. Comparing these dates to Levi's own life, parallels can be created: one finds a first temporal fragment spanning a sevenmonth block (July I943-February I944) that precedes Levi's internment in the concentration camp; a second and longer segment, which overlaps his year as a slave prisoner in Auschwitz (February I944-January 1945); and a third part forming yet another seven-month block January I945August 1945) whose vicissitudes are retold in his work La tregua (The Reawakening), the sequel to Survival in Auscbwitz. In fact, Nicholas Patruno claims that The Reawakening "may be considered this work's [If Not Now, When?] direct antecedent since it too recounts the pilgrimage through central Europe of a group of prisoners."

While in Auschwitz, like the majority of concentration-camp prisoners, Levi did not have a chance to participate in organized revolts against the Nazi machine (other than his own valiant struggle against death). Like most other Auschwitz inmates, he was kept unaware of any external partisan actions against the Nazis. Since the prisoner Levi could not fight against the Nazis nor against the civilians' general indifference, Levi lets the characters of If Not Now, When? do it for him instead. 
Retelling, orally or in written form, a difficult part of one's life can be a constructive way of coping with past pains. Primo Levi recognized the value of this kind of logotherapy through the Yiddish proverb that he used as epigraph of The Periodic Table (Il sistema periodico, 1975): "Ibergekumene tsores iz gut tsu dertseyln" (It is good to talk about overcome troubles). $\mathrm{He}$ also inserts the proverb into the text of If Not Now, When? (300). Through the fictional re-creation of an alternate life story, one might learn to cope with past senseless losses and suffering, both of one's people and of the self. The narration of traumatic memory helps turn a forcibly passive experience into an act of logotherapy, which is validating, for the survivor exercises personal choices by controlling the perspective. Narrating becomes a moment of free will and of personal autonomy. In a well-thought-out and provocative study, Susan Brison analyzes the interconnections between trauma, memory, and personal identity. She asserts that "survivors of trauma frequently remark that they are not the same people they were before being traumatized." She differentiates between different types of traumatizing events in her study, focusing on those which are "of human origin and ... intentionally inflicted."4 The narrative self, argues Brison, aids the embodied self in dealing with the aftermath of the trauma. She points out that several Shoah survivors used pseudonyms for their postwar writings (Améry and Celan, to name two) in the attempt to construct a new authorial self, after their original self had been annihilated by the perpetrators. ${ }^{5}$ Others yet wrote their autobiographies of survival in a new, adopted mother tongue (Elie Wiesel, for instance). "Not to be heard," argues Brison, "means that the self the survivor has become does not exist. Since the earlier self died, the surviving self needs to be known and acknowledged in order to exist." " Levi may have written If Not Now, When? in light of his need to be heard, then, and to validate his desire to have experienced life as a freedom fighter. Karin Lorenz-Lindemann clarifies, "The trauma transformed into language involves a process which binds self-determination to the constitution of self in mutual speech. Even more: the continuity of life realized through speech is self-assertion creating a future."”

The title of Levi's novel Se non ora, quando? stems from words found in the Talmud. Among The Maxims of the Fathers (I:I3), Rabbi Hillel stated: "If I am not for myself, who will be for me? And even if I think of myself, what am I? And if not now, when?" From Rabbi Hillel, Levi extrapolates only the last question, leaving undeveloped those expressing concern for oneself. What Levi retains for the title, instead, is the temporal question, 
"If not now, wherl?" This choice does not appear to be simply a coincidence, for temporality forms the almost obsessive backbone of the novel's story line, in which Ashkenazi pariioans take care of themselves in the underworld of the resistance ("If I am not for myself, who will be for me?") while defining their own lives and roles within their outlawed brigade ("And even if I think of myself, what am I?").

In the novel, the protagonist, Mendel Nachmanovich Dajcher, worked as a watch repairman before joining the partisans. Temporality, thus, is not only visible in the title of If Not Nozw, When? or in the almost too precisely chronologically ordered chapters, but it is also embodied within the plot's main character. Mendel is he who fixes watches, he who controls time on a watch, he who is in control of time. Mendel the partisan is "better at mending things than at blowing them up" (85). By contrast, Levi the prisoner lived his days and nights in a slavery dictated by the passing of sunrises and sunsets, by cyclical spasms of hunger, despair, and survival subject to the passing of time over which prisoners had no control. Thus here, Primo Levi the prisoner delegates to his doppelganger, Mendel the partisan, how to fix, manipulate, channel, and coordinate time: allegorically, with the watches Mendel mends, more tangibly, by his authority to decide the timing of partisan actions in his brigade. Mendel has control over time. Or, at least, Levi would like his readers to believe that he does.

Issues pertaining to the temporal perception of human beings (as well as to the loss of a time line) are themes to which Levi often turns in his works. Already as early as in his Survival in Auscbwitz, Levi connects temporal awareness (in terms, for instance, of the passing of days, hours, minutes) to the sense of preservation of human dignity. In If Not Now, When? time forms the underlying factor for each chapter, in contrast to the loss of temporal perception in Auschwitz. Possibly, Levi intends to highlight the concept of "time" as one of a human invention, and of "loss of time" as a condition that deprives humans of some of their own parameters. Patruno writes that there is a "feeling of sensory deprivation that comes from not knowing what time it is." In the same light, Brison states that "the ability to form a plan of life is lost when one loses a sense of one's temporal being, as happened to Levi and other prisoners in Auschwitz."s

Mendel recounts that when he was young, the people in his village judged the hour by the position of the sun and the moon, or by listening to the time announced on the radio. Then, when personal watches became somewhat more affordable and available, some villagers started wearing them. Watches, explains Mendel, are like people, whom he sometimes sees 
in terms of clockwork in need of repair. Early on in the novel, Mendel compares Leonid (another main character) to a dusty watch whose mechanism needs to be taken apart completely, cleaned with gasoline, and fixed (46). Patruno notes that "Leonid, who is nineteen years old, is a bookkeeper by training. At sixteen, he was imprisoned in the Lubyanka Prison in Moscow for stealing a watch. This establishes the link between Leonid and Mendel."' When comparing human beings to watches, Mendel also points out how some clocks are brought in for repair when the damage done is already irreparable. Primo Levi is implying, then, that certain types of time cannot be corrected; in other words, that certain types of people cannot be mended, certain types of situations cannot be changed.

In If Not Now, When? "control" over time, however, does not mean that time passes in a regular and predictable flow. In fact, the general confusion of wartime (historical time, political time, personal time) is mirrored structurally and stylistically in the novel. Some characters appear and disappear abruptly; often, factual information is fragmentary at best, while Levi carefully avoids long descriptive or narrative passages concerning only one character.

Within this narrative tension, a more canonical and developed form of confessional monologue would be inconceivable. In fact, through rigorous mathematical and statistical analyses of Levi's prose usage in If Not Now, When?, Jane Nystedt has demonstrated that the novel is overwhelmingly composed in dialogic form. She acutely observes that the characters' thoughts and the narratives of their brave assaults are included mostly within dialogic narrative patterns (Io0).$^{10}$ As in a puzzle taking shape, or as in a clock ticking out of sync with time, using dialogues among the novel's characters, Levi employs a quick narrative pace to describe partisan sabotages, combat techniques, moments of respite, friendships forming and dissolving by coincidence, while pondering upon life's contingencies and its needs.

In Levi's own months in Auschwitz, as well as in this novel, death is omnipresent, enormous in its irreversibility: it is irreparable, like a very badly broken watch. When the heroic partisans of Gedaleh's group are killed (and these are characters with whom the reader has become thoroughly familiar), their lives are liquidated shockingly fast. ${ }^{11}$ Levi presents death in its abruptness, as most of the time death does not allow for proper forewarning. In fact, the characters of Adam, Leonid, and Black Rokhele disappear from the plot as suddenly as they had appeared, hardly ever to be remembered again. In the narrative, the deaths of Vadim and Ber are of concern to Dov only because the perceived "Semitic physiognomy" of 
Ber's abandoned corpse may reveal the presence of Jewish partisans to the Nazis patrolling the territory of Novoselki (94-95).

The psychological profiles of the characters in this book span the whole human gamut, from the meek and fearful to the impatient and bold. Correctly, Patruno points out how the characters "retain[ed] their dignity in the midst of upheaval."12 Eamonn Callan writes that "our culturally dominant institutions about heroism revolve around the notions of the glorious and the great." ${ }^{13}$ Levi never falls into this trap, and he is able to appreciate the microcosmic yet valiant forms of resistance of any human action. Callan recalls Levi's own words in describing the different types of courage exhibited by some of his characters in If Not Now, When?: "Ulybin's courage was stubborn and dull, a duty courage that seemed the fruit of study and discipline rather than a natural gift"; "Gedaleh's courage was extempore and varied"; "where Ulybin calculated, Gedaleh flung himself as into a game." 14 The continuous balancing and intertwining play between the attributes of "patience" and "courage," Callan claims, forges the moral and intellectual landscape of Levi's characters in If Not Now, When?

When time slows down, during quiet, nocturnal, introspective moments, the characters discover their inner selves. Their self-discovery leads to an attempt at understanding the historical times and spaces of Eastern European Ashkenazi Judaism, and specifically of the identity of Russian Jews. In Levi's narrative, this search for the tradition of the fathers is present in religious and agnostic partisans alike. ${ }^{15}$

Levi writes in If Not Now, When? about those Ashkenazim for whom their Jewish ancestry, culture, and religion played an important role. By contrast, Primo Levi's Jewish identity felt, as Levi himself clarified, almost imposed upon him by the racial laws of $x 938$ and by his subsequent internment in Auschwitz. Lorenz-Lindemann points out that, as in the case of Jean Améry, "before their deportation to Auschwitz, they both lived in a context where being Jewish was not an object of particular concern. They both were arrested as members of the resistance."16 Levi dealt with the Jewish label, which the Nazis and Fascists had attached to him, but never in the sense of being a fervent Zionist or a religious man. For his whole life, Primo Levi remained an agnostic, secular Jew. His Jewish identity was something that Levi did not recognize in himself before his arrest, and he still struggled to define it fully after the war.

Primo Levi did not speak Yiddish (he only had a basic knowledge of the language, leatned after the war), was not familiar with the culture of the Ostjuden, and was attracted to their history of resistance during World War II. The only extended exposure that Levi had with the world of the 
Ostjuden was while in the Lager. In Auschwitz, Levi was surrounded by thousands of Ashkenazim, who spoke Yiddish as their lingua franca. For Levi, such a linguistic connection was an intriguing experience, because, overall, Italian Jews (Sephardim and Italkim) do not speak nor understand Yiddish; rather, they share different kinds of ties with one another and within their community. After the war, Levi wished to explore further the Jewish identity of Eastern Europe. In If Not Now, When? Levi reconstructed a world, a culture, a language, which, to a large extent, was unknown to him. ${ }^{17}$ The novel can be regarded as Levi's attempt to introduce the culture and the traditions of the Ashkenazim and of the Yiddishspeaking Jews to the Italian readership..$^{18} \mathrm{It}$ is in this light that one should read, toward the end of the novel, the lack of interaction between Gedaleh's group and the other guests at the reception by Signora Adele S. and her husband in Milano. This episode underlines the isolation and separation between the Ashkenazim Zionists and the Italian Jews. It further emphasizes how, to a certain extent, Italian secular Judaism was, and is, a somewhat indefinable state of being, based not solely upon a religious belief (or lack thereof), but also by the knowledge (or lack thereof) of a common language such as Yiddish. As one reads in If Not Now, When?, "Redest keyn jiddisch, bist nit keyn jid": If you do not speak Yiddish, you are not a Jew (20I).

A declared agnostic, Primo Levi is valued by many readers as a humanist writer rather than as a "Jewish" author. However, his agnosticism notwithstanding, biblical themes penetrate his works. References to the Hebrew scriptures and to Judaism abound in If Not Now, When? As mentioned previously, the title itself is part of the Talmud, to which Levi added a contemporary twist. ${ }^{19}$

Do you recognize us? We're the sheep of the ghetto,

Shorn for a thousand years, resigned to outrage.

We are the tailors, the scribes and the cantors,

Withered in the shadow of the cross

Now we have learned the paths of the forest,

We have learned to shoot, and we aim straight.

If I'm not for myself, who will be for me?

If not this way, how? And if not now, when?

Our brothers have gone to heaven

Through the chimneys of Sobibor and Treblinka,

They have dug themselves a grave in the air.

Only we few have survived 
For the honor of our submerged people, For revenge and to bear witness.

If I'm not for myself, who will be for me?

If not this way, how? And if not now, when?

We are the sons of David, the hardheaded sons of Masada.

Each of us carries in his pocket the stone

That shattered the forehead of Goliath.

Brothers, away from this Europe of graves:

Let us climb together towards the land

Where we will be men among men.

If I'm not for myself, who will be for me?

If not this way, how? If not now, when? (I68-I69)

This poem is remarkable for several reasons. In it, Levi summarizes the highlights of the history of European Jewry, of its survival and the dignity of its culture. Once viewed by outsiders merely as the sheep of the ghetto, Jews instead claim for themselves a long tradition of active involvement in their communities. In the poem, Levi points out that Jews worked as tailors, clothing people in outfits that mirrored the many different positions Jews held within the larger society. They were scribes, both in the sense of the sacred profession that creates letter-perfect Torah scrolls, but also in the sense of those who wrote the history of the Jewish people, and the history of the holy books. They were cantors, chazzanim, who gave life, voice, and sound to the complex art of Jewish music. While for centuries they lived as minorities in the lands of Christians, being at times ostracized and at times tolerated "in the shadow of the cross," during the resistance in World War II, they left their established communities to take refuge in the forests nearby, claiming for themselves a small resemblance of freedom that they were being denied in the ghettos. As freedom fighters, Jews traded their former jobs as tailors, scribes, and cantors to become sharpshooters instead, ready to engage in violence when necessary to uphold their right to human dignity, making sure never to be mistaken again for sheep in the ghetto. The freedom fighters knew, Levi continues in the poem, what happencd to the Jews who had been deported from their towns: they were burned in the crematoria and "gone to heaven through the chimneys." Thus, those who engaged in partisan combat did so in order to try to change the course of the genocide; to stay alive in order to write the history of a most courageous survival, and to bring both honor and revenge to a people whose civic and intellectual contributions to European history were inarguably seminal. The last strophe of the poem 
emphasizes the long history of courage of the Jewish people: their biblical ancestral lineage as children of King David who, still a youngster, slew the giant Goliath with just one perfect shot of his sling. Also, Levi brings forth Jews' legacy as defenders of freedom as he points the reader to the episode of the heroic resistance of 960 Jews on the isolated mountaintop of Masada. They committed suicide rather than give themselves up to be subjected to the Romans. Still today in Israel, Masada is the emblem of Jewish survival. All partisans, concludes the poem, are brothers, there to help each other, to take their own destiny into their own hands, for no one else will do it for them. The last lines of the third strophe leave the reader with an unmistakable call to Zionism, with the desire to leave behind "this Europe of graves."

As Patruno recognizes, Gedaleh's song is of "resurrection and triumph," as it also gives the title to the book. It is "the real turning point in the story. After this night, there is more purpose and direction." ${ }^{\prime 20}$

In his novel, based on much historical evidence of Jewish partisan action, Levi stressed how European Jews were not passively resigned to their destiny, and did not go to the slaughter like meek sheep without fighting. "Levi is inventive in devising and describing subversive actions, displaying a familiarity with the basics of guerrilla tactics that seems remarkable considering the short time he spent as a partisan in Italy."21 For the millions killed in the genocide, there were thousands of organized Jews and Gentiles who attempted to resist the Nazi machine of annihilation.22 The refrain of Gedaleh's song emphasizes the importance of personal contributions to political and ideological movements. Patruno states that "to those who have questioned the behavior of Jews during the Holocaust, this tale of collective and individual heroism and resistance is a powerful response." Moreover, Patruno observes that the novel is "Levi's answer to all those who have demeaned the Jews for not resisting."

Usually not heavily and overtly politicized in his writings (and I propose that here the readers are witnessing yet another aspect of Plimo Levi's alter ego), in If Not Now, When? the author stresses individual and political obligations toward society by placing the character of Mendel at the center of the narrative. While obviously not all Jews and Gentiles are mandated to play the biblical role of each other's keepers, nevertheless Levi stresses the moral responsibility of a shared civic duty in guaranteeing democracy for a free society. Primo Levi, in the true spirit of a secular Jew, offers no definite parameters for these considerations: rather, to each person his or her own solution, forged by the result of a long inquiry with one's conscience, exercising personal moral principles and ethics. Jews were forced 
to take care of their own protection during World War II; during the years of genocide, "no manna descended from the black sky, but only pitiless snow. Let each choose his own destiny," writes Levi (96). The degree to which one becomes the brother's keeper or the brother's killer (or the 'gray zoner' in between, for that matter) depends only on one's self, the author concludes. ${ }^{21}$

Toward the end of the novel, the Gedalists are taken to Glogau, a German mining center liberated by the Russians only a few weeks earlier. For the first time in the narration, the partisan unit finally freely engages in conversation with some ex-prisoners of the Nazi camps. A new character is introduced, the Auschwitz survivor and "assimilated" Jewess Francine. She fleetingly appears in the novel and then disappears, never to be mentioned again, for her fictional life spans just a few, short, but solidly built, paragraphs. Like Primo Levi, she too, at the moment of her arrest, had declared herself Jewish; she, too, did not speak nor understand Yiddish; she, too, had a well-proven scientific background, having practiced pediatric medicine professionally in Paris before her deportation. Her character is strong: no longer the woman with "eyes empty and womb cold / as a frog in winter" whom Levi had described in his poem "Shemà," the epigraph of Survival in Auscbwitz. Francine therefore represents and behaves as a proud exception to the genocide. It is Francine who explains the overwhelming sense of guilt she bears for having survived the camp experience while many of her Jewish friends and relatives succumbed. Levi will wait until his I sommersi $e$ i salvati (I986, The Drowned and the Saved) to address and discuss more directly and openly the topic of survivor's guilt in one of his chapters. It is apparent, however, that this subject already weighed on Levi while he wrote If Not Now, When? Francine represents all the prisoners who survived the Shoah and paid a hefty psychological price in terms of bearing the weight of their memories. Memories of the loved ones who did not survive, memories of those prisoners who followed-for better or for worse-their own instinct of survival, memories of the uncontrollable and arbitrary external factors that kept one person alive, while another one died. Francine then explains how the feeling of guilt for having survived the Shoah (vis-à-vis the next of kin who perished during the persecution) brought many survivors to commit suicide after the liberation. Like Levi, she had not been in contact with Eastern European Jews before her internment in Auschwitz; like him, she could not identify close spiritual affinities with those actively involved in Zionism. She considered herself first and foremost French and was not able to define clearly in what consisted her Jewishness, just as the secular Primo Levi thought of himself as an Italian 
citizen first and foremost, surrounded by many Italian Christian friends for whom his Jewishness was at best of little significance, since he had never been an observant Jew. The fictional Francine typifies the hundreds of courageous survivors who were able to identify and express their feelings of shame and guilt for a second chance at life, which they perceived as not having been earned. ${ }^{25}$ "It's hard to explain," comments Levi's female alter ego (295). Within a different context, Douglas Kellner writes that "in pre-modern societies, identity was unproblematic and not subject to reflections of discussion. Individuals did not undergo identity crises, or radically modify their identity. ${ }^{.26}$ The characters in Levi's novel are fully modern in this sense, for most experience deeply moving or troubling moments of brutally honest soul searching.

The novel ends on Tuesday, August 7, 1945. Twenty-five months have passed since the first pages of If Not Now, When? As Giuseppe Tosi correctly observes, If Not Now, When? opens with one of Mendel's many flashbacks, indicating a general timelessness of events in the opening sentences, and ends with a specific temporal marker: Hiroshima, August 7, 1945. The whole novel is set in between these two temporal posts. By the end of If Not Now, When? time has passed for Mendel the watch repairman; time has passed for the reader. As the character named White Rokhele gives birth to Isidor's son at a hospital in Milano, doctors read headlines about the American atomic bomb's killing of tens of thousands at Hiroshima. At the moment of the atomic blast all the clocks in Hiroshima were destroyed, and time stopped in Japan. By contrast, for Mendel the watch repairman, the timekeeper, he who can fix the link between past and present, time continues to go by. Time ticks also for the newborn, and time goes on for Zionists on their way to Palestine. The tragic final tone of the novel certainly dampens the joy of a new birth: built around the suffering and deaths of World War II, the book ends with an image of death. The reader is led to ponder the juxtaposition between the preShoah memories and the tragic turn of events during the war. Often in Levi's works, life and death are intertwined, therr intrinsic connection hard to put in plain words. Tosi comments that this contrast is further exacerbated by a disintegrated and disintegrating past, leading to a future whose parameters need to be invented anew. ${ }^{27}$ To paraphrase Primo Levi, "the drowned" and "the saved" are not necessarily two separate groups of people: sometimes one can survive a traumatic experience, while at the same time succumbing to it.

Perhaps Levi wrote this novel in an attempt to indicate the meaning of life to the next postwar generation. To quote Lorenz-Lindemann, "Jewish 
tradition has taught us that it belongs to the tasks of men to recreate the world: Levi has tried just this-through writing. That was his revolt." It could likewise be argued, as Callan does, that "yet the limits of our capacity to make the good we crave our own are often intractably narrow."28

At the end of If Not Now, When? time goes on, but only for those surviving characters who are now utterly aware of the death surrounding them. The atrocities of World War II have become the inherent legacy of the new postwar generation. It appears, then, that in his novel the author Primo Levi trades places with the character Mendel: when the first was prisoner in Auschwitz, the latter was on the forest trails fighting with the partisans. In fact, in a 1982 interview, Primo Levi stated, "I did identify with Mendel. What I mean is that he did what I would have done, orbetter yet-what I should have done, had I been capable of doing it." ${ }^{\prime 29}$

Besides Levi trading places with Mendel, Mendel trades places within himself, too: after spending one erotic night with Line at the mill, a perturbed Mendel engages himself in a deep soul-searching moment (I94). ${ }^{30}$ Mendel the factotum, Mendel the watch repairman, perhaps the most rational character in the novel, is surrounded by ghosts, for the shadow of his deceased wife, Rivke, never abandons him. The character Francine's explanations of "shame" and "guilt" apply to Mendel, too.

If Mendel represents Levi's doppelganger, then Levi's ghosts are likely hidden through Mendel's. Mendel's stream-of-consciousness thoughts reveal the weight of the past during one of the most introspective moments of If Not Now, When?:

He pressed, tried to draw her to him, but Sissl resisted, stony in sleep. On the vague screen of his dozing, names and faces pursued one another, present and distant. Sissl, blond and tired. Rivke with her sad black eyes, but Mendel dispelled her at once, he didn't want her, he couldn't think about her. Rivke, Strelka, the grave: go away, Rivke, please. Go back to where you came from, let me live. (192)

It is in this text, perhaps, that the seed was planted for Levi's later poem "The Survivor" (I984): "Stand back, leave me alone . . / go away ... / go back into your mist," pleads the survivor at bedtime, in need of sleep, but overwhelmed by the same sense of guilt that Francine tried to explain to others.

To conclude, 1 should point out that in If Not Now, When? one reads, "This story is not being told in order to describe massacres" (98). The problem with Weaver's translation of this sentence is that, traduttore traditore, it does not tender the original, "Non è per descrivere stragi cbe questa 
storia sta raccontando se stessa" (64). "This story is narrating itself" is actually what Levi writes. As time passes, Levi suggests, life has a way of creating itself often independently of our control. Life narrates itself, the story narrates itself.

In significant ways, then, Levi is the watch repairman of this novel, which narrates itself while at the same time narrating the protagonists' fictional lives and mirroring the author's most inner thoughts. Levi's own search for identity is veiled and masked within the narrative, his own existentialist search remaining apparently dampened, apparently secondary only to Mendel's. ${ }^{31}$

An unsettled author hides within the lines of If Not Now, When? $\mathrm{He}$ searches for answers to many questions: questions about life and death, questions about choices not made, questions about the arbitrariness and necessities in life, questions about history created or history suffered, about control over one's life, about the guilt of survivorship, and, in general, about life's roads, the paths, and the forest trails, taken or not: Levi, the denied partisan; Levi, the Auschwitz survivor. 
$\checkmark$ 8. THE PARTISAN AND HIS DOPPELGANGER: THE CASE OF PRIMO LEVI Ilona Klein

r. Translated by William Weaver, If Not Now, When? was published in English in 1985 . In Italy it reaped immediate success, praised by both critics and readership alike, and Levi was awarded the Premio Viareggio and the Premio Campiello in 1982. This was his second Campiello, having also won "it nine years earlier with La tregua (The Truce).

2. See also the chapter "Gold" in Levi's The Periodic Table.

3. Nicholas Patruno, Understanding Primno Levi (Columbia: University of South Carolina Press, 1995), 90.

4. Susan J. Brison, "Outliving Oneself: Trauma, Memory, and Personal Identity," in Feminists Retbink the Self, edited by Diana T. Meyers (Boulder: Westview, 1997), I2, I4.

5. One might certainly add Damiano Malabaila (Primo Levi's nom de plume for Storie naturail) to this list, too.

6. Brison, "Outliving Oneself," 29.

7. Karin Lorenz-Lindemann, "Wieviel Heimat braucht der Mensch? Aspects of Jewish Self-Determination in the Works of Jean Améry and Primo Levi," in The Fewish Self-Portrait in European and American Literature, ed. Hans-Jürgen Schrader, Elliott M. Simon, et al. (Tübingen: Niemeyer, r996), 228.

8. Patruno, Understanding Primo Levi, 93; Brison, "Outliving Oneself," 22. 9. Patruno, Understanding Primo Levi, 93.

Io. Jane Nystedt, "Lunghezza della frase e interpunzione: Mezzi stilistici in Primo Levi," Studi Italiani di Linguistica Teorica e Applicata 2 I, nos. I-3 (I992): 100.

II. As examples, one can look at Leonid, the introvert young Jew from Moscow, paratrooper and bookkeeper; and at Black Rokhele, a twenty-yearold veteran who was as strong as any of the men in the unit. Both perish from sudden bullet wounds. Their names are hardly mentioned again in the novel after their deaths.

I2. Patruno, Understanding Primno Levi, 91.

I3. Eamonn Callan, "Patience and Courage," Pbilosophy 68, no. 266 $(1983): 528$.

I4. Ibid., 536 .

I5. Personalities and beliefs range from those of White Rokhele, the widow of a rabbi, not too religious herself, to Mendel, who is continuously searching his soul to find the meaning of God, the meaning of war, the meaning of his ancestral traditions.

I6. Lorenz-Lindemann, "Wieviel Heimat braucht der Mensch?" 224. 
17. One of the characters in the novel is the Christian Russian Piotr Fomich, who believes in Jewish and anti-Nazi resistance to the point of putting his own life on the line more than once for Gedaleh's comrades. This character represents he who must be initiated gradually into the fundamental principles of Judaism. He does not know about, nor has he ever read, the Talmud. The other partisans compare the Talmud for him to a soup with several different and sometimes contrasting edible ingredients among which each Jew may subjectively choose.

I8. Tosi points out that the Italian editions of both The Truce and If Not Now, Wben? include sketched maps to aid the reader in negotiating the geographic areas of the narrative.

I9. Located in the center of the novel in the chapter entitled "May 1944," the lyxics celebrate Gedaleh's camp. The group sings and dances around the campfire, in one of the few moments of respite experienced by the partisans throughout the storyl Late that night, after most members are sleeping off the fumes of alcohol, Gedaleh takes his violin and plays a brisk tune learned at the Kossovo ghetto. Character Martin Fontasch (a peaceful carpenter) was the author of the words he had composed half an hour before dying at the hands of a Nazi.

20. Patruno, Understanding Primo Levi, I03.

2 I. Tbid., ror.

22. The film Defiance, directed by Edward Zwick, was released in the United States in 2008.

23. Patruno, Understanding Primo Levi, 92, 106.

24. See Primo Levi's own definition of a moral gray zone, in the chapter by that name in his The Drowned and The Saved.

25. Claude Lanzmann's documentary film Shoab (1985) is filled with interviews in which such anguish is present in each person discussing his or her survival. These Jews perceive their being alive as a privilege not earned. The overwhelming pain of memories, together with the observation that the events of the Shoah find no logical explanation, led some survivors to suicide.

26. Douglas Kellher, "Popular Culture and the Construction of Postmodern Identities," in Modernity and Identity, ed. Scott Lash and Jonathan Freidman (Cambridge, Mass.: Basil Blackwell, I992), I4I.

27. "Al passato distrutto si associa il dissolvimnento del futuro... non disponendo di modelli di riferimento cbe affondano le loro radici nel passato." Giuseppe Tosi, "Dall'attesa alla storia-esilio: La memoria e l'identità in Se non ora, quando? di Primo Levi," Annali d'Ttalianistica 20 (2002): 287.

28. Lorenz-Lindẹmann, "Wieviel Heimat braucht der Mensch?" 230; Calkan, "Patience and Courage," 539.

29. "Mi sono effettivamente indentificato con Mendel: Voglio dire che lui fa quello che avrei fatto io, o meglio quello che avrei dovuto fare io, se ne fossi stato capace." 
Interview with Rossellina Balbi La Repubblica, April 14, I982. Quoted from Marco Belpoliti, Primno Levi: Conversazioni e interviste: $1963-1987$ (Turin: Einaudi, I997), I32.

30. On one hand, the character Mendel needs to be free of all romantic ties so as to reinstate trust and sincerity in his camaraderie with Leonid. On the other hand, Mendel needs the support of a woman in his life, after the tragic death of his wife Rivke, killed by the Nazis in Strelka.

3x. When Mottel askes about Italy, this answer comes:

Italy is an odd country. . . . The Italians don't like lawrs: in fact, they like disobeying them: it's lheir garne, like the Russians' game is chess. ... The Italians have proved to be friends of all foreigners. . . They helped us not in spite of the fact we're Jews, but because of it. They also helped their own Jews; when the Germans occupied Italy, they made every effort they could to capture the Italian Jews, but they caught and killed only a fifth. ... Iven as Christians, the Italians are odd. They go to Mass, but they curse. ... They know the 'Ten Commandments by heart, but at most they observe two or three. I believe they help those in need because they're good people, who have suffered a lot, and who know that those who suffer should be helped. ... Italian Jews are as odd as the Catholics. They don't speak Yiddish, in fact they don't even know what Yiddish is. They only speak Italian; or rather, the Jews of Rome speak Roman, the Jews of Venice speak Venetian, and so on. They dress like everybody else; they have the same faces as everybody else. ... The Christians don't give them any thought, and they themselves don't think much about being Jews....

There, this is the country you're entering: a country of good people, who don't much like war, who like conlusing issues. ... This is really the ideal place.

$(323-325)$ 